\title{
Three Regional Dialects in Turkey
}

\author{
Meryem Karlık, Azamat Akbarov \\ Department of Foreign Languages and Literature, International Burch University, Sarajevo, Bosnia \& Herzegovina
}

Email address:

meryemkarlik@hotmail.com (M. Karlık), azamatakbar@yahoo.com (A. Akbarov)

\section{To cite this article:}

Meryem Karlık, Azamat Akbarov. Three Regional Dialects in Turkey. International Journal of Language and Linguistics. Vol. 3, No. 6, 2015, pp. 436-439. doi: 10.11648/j.ij11.20150306.27

\begin{abstract}
The purpose of this article is to show whether Konya, Çanakkale and Manisa dialects have a diglosic feature or not and how the usage of the components of diglossia is seen in these cities. In order to determine High or Low varieties of the Turkish Language, these three dialects are compared to Istanbul dialects. These cities are different part of Turkey and every of them have migration from other cities. So people are using Low variety in their daily lives even they are supposed to use High variety of Turkish Language when it is a necessity. However, they have communication problems in their conversations in both High and Low variety forms of Turkish Language. We explain similarities and differences between these three dialects comparing with Istanbul dialects via given examples and tables. How people are using the language and even one word cannot be similar to other dialect is shown. Moreover comparing words and verbs with their meanings which are changing in some situations completely would be beneficial in order to understand the diglossic issues in Turkish Language.
\end{abstract}

Keywords: Diglossia, High Variety, Low Variety, Turkish Language

\section{Introduction}

Sociolinguistics is the study of the language which has relation to the society. It has investigated new phenomena such as language varieties, speech communities, colloquialism, vernaculars, dialects, the functions of different language varieties within communities and diglossia. Diglossia refers to "the presence of a high and a low style or standard in a language, one for formal use in writing and some speech situations and one for colloquial use" (Harris and Hodges, 1981). Sociolinguistics concerned with diglossia which in many speech communities, there are languages which has two or more varieties under different conditions. Preston (1989) argues that the study of regional dialects must be carried out both in terms of the systematic analysis of their internal linguistic properties, as well as in terms of how language users respond to and evaluate those dialects.

Mainly, diglossia divided into two varieties; L (low variety) and $\mathrm{H}$ (high variety) and each of them is used in different circumstances for different functions. L is usually used in informal whereas $\mathrm{H}$ is used in formal conversations. $\mathrm{H}$ is highly valued than $\mathrm{L}$. $\mathrm{H}$ is used in literature, religious texts, public speaking and education whereas $\mathrm{L}$ is felt less worthy and used in jokes, street and market, home (Ferguson, 1959). In most cases L is not used in literary forms, except for 'dialect poetry' or advertising. But $\mathrm{H}$ is used for literature.
We can say that $\mathrm{L}$ is mother tongue which is first learned at home while $\mathrm{H}$ is learned at school. $\mathrm{H}$ is standardized by grammar in literary form by native linguistics while L standardized in traditional sense. So, $\mathrm{H}$ has more complex grammar than L. $\mathrm{H}$ and $\mathrm{L}$ share the same phonological elements but $\mathrm{H}$ has more complicated morphophonemic (Alshamrani, 2012). Diglossia is not limited for specific area or language family, it has existed for centuries. In diglossia, L dialect is spoken as a mother tongue while in $\mathrm{H}$ dialects no one speaks. In this paper, we will evaluate different dialects in Turkish Language from three different part of Turkey.

\section{History of the Turkish Language}

\subsection{Altay Language Association Period}

It is considered as a dark period that Turkish still is not separated from Altay Languages. (Mongolian, Manchu, Korean, Japanese)

The Oldest Turkish Period: It is considered as a period that Turkish is separated from main Altay Language as an independent language.

The First Turkish Period: It is shown as a period that Huns, Avars, Khazars, Bulgarian languages are still not separated from Turkish. (Mirşan)

Outline of Turkish which belongs to the dark ages is in this 
way. Texts belongs to the subsequent period are literary sources so historical development of the language can be traced in a healthy way. The period that Turkish can be followed with the texts is as follows:

Old Turkish Period ( $6^{\text {th }}-13^{\text {th }}$ centuries): It is the first period that Turkish followed with the documents and includes the age until $13^{\text {th }}$ century. It is the most pure and clear period in terms of phonology and morphology in taking into account all periods of Turkish. All Turks in this period have used the first of this literary Turkish language, for regular and abundant texts in order to identify the historical development and grammatical properties of the language. Texts which belong to this period are collected in three groups; Köktürk, Uygur and Karahanlı texts (Özyetgin, 2006).

Middle Turkish Period $\left(13^{\text {th }}-15^{\text {th }}\right.$ centuries $)$ : It is a transition period that connects Old Turkish and New Turkish. MiddleAsian has witnessed a number of changes and developments in general structure of Turkish language as a result of mixing and segregation. These developments and changes cause environment for arising new literary languages.

New Turkish Period ( $15^{\text {th }}-20^{\text {th }}$ centuries): It is a period that during Middle Turkish period Turkish dialects and literature continued to develop. Although there are differences in terms of grammatical structure from Middle Turkish Period, it is not possible to separate with certain lines. However, during this period, Turkish undergoes some changes due to external influences.

\subsection{Modern Turkish Period}

It includes all regions of Turkey from the $20^{\text {th }}$ century. It is the cleanest circuit of Western Turkish. During this period, Turkish rescued from foreign prepositions and noun phrases. After, numbers of foreign words are reduced and it is still decreasing. Now, the main danger for Turkish is Western Languages, especially English. In Turkey Turkish, sentence structure also has gained a large bright. In this term, Turkish sentence rescued from ancient times in form of being complex and difficult to understand. In Turkey Turkish, spoken language is based on Istanbul Turkish. Atatürk, who is the founder and leader of the Republic of Turkey, has made innovations in fields of language and thought. In 1923, Turkish is expressed as an official language in Republican Constitution. In 1928, June 6, letter revolution is made and the new Turkish alphabet is accepted. 'National Schools' are opened and simplification of the language rate is increased. "Cord between national feeling and language is very strong. Being national and rich language is mainly growth of the national feeling. Turkish language is one of the richest languages, as long as this language is treated consciously." (Atatürk, 1928). Today, Turkish ranks fifth among the most spoken languages in the world. In this ranking, the first is Chinese with over one billion population, second English pursues it, after Spanish and Hindi, Turkish comes after. The original owner of English and Spanish languages imposed by countries as a result of increasing the number of people who speaks these languages, the rank of Turkish gain more importance.

\section{Regional Dialects of Turkish}

As the other languages, Turkish also has many dialects which differ according to the region. Western part of Turkey speaks more different than eastern part. For, the society affects the language. So, the life of people or their thoughts affect their dialects. It is because of psychological and geographical identity. The language is the same but dialects of the region make it incomprehensible for other region of people. For, there are many lexical and phonological differences. As we mention that modern Turkey Turkish is spoken in Istanbul. And we can say that it is $\mathrm{H}$ variety which is thought in the schools. In other cities, dialects affect the way of speaking of the people. It can include $\mathrm{L}$ variety because you cannot use them while writing or speaking in the public place. I am going to evaluate three different types of dialect according to the region in Turkey. Because, my parents from different part of Turkey. One of them is from Çanakkale and the other is from Konya. And in my childhood, I have grown up in Manisa. So, in holiday times I am going these cities one after another. And I can understand certain differences of dialects while I am talking with people who are living there from their birth.

\subsection{Konya Dialect}

From the viewpoint of pronunciation, Konya dialect differs in that ' $g$ ' sound is used instead of ' $k$ ' sound. For example:

G1z instead of k1z (translation: girl)

Guzum instead of kuzum (translation is 'my lamb' but it is telling when you are petting your child)

Gonya instead of Konya (City of Turkey: Konya)

The ' $u$ ' sound changes into ' 1 'sound: Mihtar instead of muhtar (translation: headman)

The 'e' sound changes into 'i' sound.

Yiter instead of yeter (translation: enough)

Virdim instead of verdim (translation: gave)

The 't' sound changes into'd' sound. For example: Dut instead of tut .But here the meaning of the words are different. 'Dut' means mulberry while 'tut' means hold.

Prosthesis, the addition of a sound or syllable at the beginning of a word, can be seen in this dialect. For example; ileğen instead of leğen (translation: washbowl)

Some sound changes and drop the vowel sound: gaysı instead of kayıs1 (translation: apricot) aba instead of abla (translation: sister)

badilcan instead of patlican (translation: eggplant)

Past tense form changes like past perfect tense in English but it is wrong usage;

Unutmuşmussum instead of unuttum (translation: forgot)

Galmışsım instead of kaldım (translation: stayed)

In present continuous form, the sound ' $r$ ' dropping; gidiyon instead of gidiyorsun (translation: you are going). In some words, two sounds can be changed or one sound can be appeared:

Alettirik instead of elektrik (translation: electric) 
Güççük instead of küçük (translation: small)

Acep instead of acaba (translation: if)

Cazı instead of cad1 (translation: witch)

Piskevit instead of bisküvi (translation: biscuit)

Another characteristic of this dialect is the change in vocabulary. There are many local words in this dialect. Some of them are:

Table 1. H and L Variety of Konya Dialect.

\begin{tabular}{lll}
\hline High Variety & Low Variety & Translation \\
\hline Ne yapıyorsun? & Nörüyon-Ni diyon-Napan & What are you doing? \\
Kadın & Avrat & Woman \\
Sırtımı ov & Dalımı çiğne & Massage my back \\
Yatak & Döşşek & Bed \\
Traktör & Motur & Tractor \\
Yaramaz & Zağar & Useless \\
Morartmak & Cibartmak & To bruise \\
Ayakta durmak & Dinelmek & Stand \\
Sirt & Dal & Back \\
Altgeçit & Battı çıktı & Underpass \\
Saçma sapan & Yallı yullu & Ridiculous \\
Amca & Emmi & Uncle \\
\hline
\end{tabular}

\section{2. Çanakkale Dialect}

As in the other dialects, there are some phonologic differences in Çanakkale dialect. Some sound changes take place. Some examples of them are as follows:

The ' $a$ ' sound changes into ' $u$ ' sound: buba instead of baba (translation: father)

The ‘ö' sound changes into 'ü' sound: 'güz instead of göz (translation: eye)

The ' $h$ ' sound dropping at the beginning of the word: oroz instead of horoz (translation: cock)

The consonant sounds are dropping and pronunciation become short:

Bakem instead of bakayım (translation: see)

Süle instead of söyle (translation: say)

In most speech, they are using/ adding these words: 'abe' or 'beya'

Hadi beya! This word integrated with words 'be' and 'yahu' over time (translation: come on!)

Abe kaynana! It is an exclamation used to attract the attention of opposite. (Translation of kaynana is mother in law)

Another characteristic of this dialect is the change in vocabulary. Some of them are:

Table 2. H and L Variety of Çanakkale Dialect.

\begin{tabular}{lll}
\hline High Variety & Low Variety & Translation \\
\hline Kaçmak & Naşmak & Escape \\
Pişi & Gödek & Savory pastry \\
Çocuk & Kızan-Sıpa- Encek & Child \\
Yine & Gene & Again \\
İyi misin? & Yavız mısın? & Are you alright? \\
Kel kafalı & Susak kafalı- Akılsız & Bald \\
İstemek & İsteyip duru & To want \\
Şimdi & Şimcik & Now \\
Senin yüzünden & Senden ötürü & Because of you \\
\hline
\end{tabular}

\subsection{Manisa Dialect}

From the viewpoint of phonological differences, main vowel changes in this dialect can be summarized as it is seen below:

Eyi instead of iyi (translation: good)

Bene instead of bana (translation: to me)

Zati instead of zaten (translation: already)

Domat instead of domates (translation: tomato)

Akıdeş instead of arkadaş (translation: friend)

Dropping the consonant sound: aşam instead of akşam (translation: evening)

Changing the consonant sound: Hindi instead of şimdi (translation: now)

Dropping vowel can be seen in the middle of the word while pronouncing:

Alisan instead of Ali İhsan (Turkish man name)

Another characteristic of this dialect is the change in vocabulary. There are many local words in this dialect. Some of them are:

Table 3. H and L Variety Manisa Dialect.

\begin{tabular}{|c|c|c|}
\hline High Variety & Low Variety & Translation \\
\hline Kalemtraş & Çinti- Düzgü & Pencil sharpener \\
\hline Simit & Gevrek & $\begin{array}{l}\text { Savory roll covered with } \\
\text { sesame seed }\end{array}$ \\
\hline Ayçekirdeği & Çiğdem & Sunflower seeds \\
\hline Çamaşır suyu & Klorak & Chlorine water \\
\hline Ayakkabı & Babuç & Shoe \\
\hline Misir & Dar1 & Corn \\
\hline Doldurmak & Depmek & To fill \\
\hline Çekingen & Miymıntı- Siftik & Hesitant \\
\hline Beddua etmek & İlenmek & To curse \\
\hline Evlendirmek & Evermek & To marry \\
\hline Birazdan & Acıktan & In a while \\
\hline İttirmek & Kaktırıvermek & To stick \\
\hline Ama & Emme & But \\
\hline Demek ki & Zere & Scilicet \\
\hline
\end{tabular}

\section{Conclusion}

Most of the languages have some varieties. As we mentioned above, Turkish has regional dialects that have some phonological and lexical differences. The standard dialect in Turkey is Istanbul dialect. This can be taught in the schools from the primary education. But you cannot learn another dialect of the Turkish at the classroom. So, immigration from the eastern to western part of Turkey or vice versa has increased the learning dialects among the people. Of course, people are not assimilating to one another. Specifically, our results demonstrate that several significant, systematic gender and age based patterns emerge in a study which investigates the perceptions and evaluations of Turkish regional varieties by Turkish non-linguists. Thus, it appears to be the case that gender and age, at least, are influential social factors not just in language production, but in conscious language evaluation as well (Demirci, (1998). Your dialect cannot be changed if you have not lived there more than ten years. Maybe you can get some of the words in everyday speech in order to communicate with the people 
(Şen, 2004). For, some dialects are difficult to understand even if you are Turk. Learning one more word does not lose anything from you. On the contrary, sometimes you really get fun when you learn different dialects. So, just open your mind for new knowledge and appreciate the life.

\section{References}

[1] Alshamrani, H. (2012). Diglossia in Arabic TV stations. Journal of King Saud University-Languages and Translation. 24 (1), 57-69.

[2] Atatürk, K. (2000). Nutuk (Söylev). Kaya Yayınları.

[3] Demirci, M. (1998). Gender and Age-based Variation in the Perception of Turkish Dialects, Language Awareness, 7 (4), 206-222.
[4] Ferguson, C.A. (1959). Diglossia. Word, 15, 325-340.

[5] Guise, John. (2014) The Turkish Language Explained For English Speakers. ManisaTurkish.1 Edition.

[6] Harris and Hodges. (1981). A Dictionary of Reading and Related Terms. International Reading Association, Newark, DE.

[7] Mirşan, K. Türk Dili Tarihi. http://turkdili.gen.tr/tuerk-dilitarihi.html.

[8] Özyetgin, M. (2006). Tarihten Bugüne Türk Dil Alanı. Ankara.

[9] Preston, D.R. (1989). Perceptual Dialectology: Nonlinguists. Views of Areal Linguistics. Dordrecht: Foris.

[10] Sen, M. Baykal, N. (2004). Evaluational Reactions of Standard Accented Turkish Speakers Towards Accented Speech and Speakers. (http://www.inst.at/trans/15Nr/06_1/sen_baykal15.htm). 